University of Florida Levin College of Law

UF Law Scholarship Repository

UF Law Faculty Publications

Faculty Scholarship

2020

\title{
Minding the Gaps in Regulation of Do-it-Yourself Biotechnology
}

\author{
Barbara J. Evans \\ University of Florida Levin College of Law, evans@law.ufl.edu
}

Follow this and additional works at: https://scholarship.law.ufl.edu/facultypub

Part of the Medical Jurisprudence Commons

\section{Recommended Citation}

Barbara J. Evans, Minding the Gaps in Regulation of Do-it-Yourself Biotechnology, 21 DePaul J. Health Care L. (2020)

This Article is brought to you for free and open access by the Faculty Scholarship at UF Law Scholarship Repository. It has been accepted for inclusion in UF Law Faculty Publications by an authorized administrator of UF Law Scholarship Repository. For more information, please contact kaleita@law.ufl.edu. 


\section{Minding the Gaps in Regulation of Do-it-Yourself Biotechnology}

Author: Barbara J. Evans, Ph.D., J.D., LL.M, taught at University of Houston from 2007 - 2020 and recently joined the University of Florida as Professor of Law and Stephen C. O'Connell Chair at the Levin Law School and Professor of Engineering at the Wertheim School of Engineering, evans@law.ufl.edu.

\section{Introduction}

This Symposium confronts the reality that genetic technologies - not just genetic tests, but tools for altering plant, animal, and human genomes - are rapidly becoming and indeed already are consumer technologies. People can experiment with and apply these technologies in disintermediated formats, potentially without the involvement of national research funding agencies, professional scientists, physicians, genetic counselors, regulators, and traditional medical product manufacturers. The framework of $20^{\text {th }}$-century medical product and practice regulations assigned each of these parties a role in promoting ethical, safe, and effective biomedical research and health care. ${ }^{1}$ Do-it-yourself biotechnology (DIYbio), which includes direct-toconsumer (DTC) and do-it-yourself (DIY) genomic technologies, threatens to disrupt these roles. This raises concerns about how to protect consumer safety, the safety of research participants, and environmental and public safety to the extent these technologies are deployed in uncontained, open-release applications. $^{2}$

Some of these concerns relate to the mechanics of regulation - for example, how to stretch existing regulatory principles and authorities to cover novel products and delivery pathways. Yet these technologies also raise questions about the very goals of regulation, forcing us to reexamine first principles such as, "What is the regulatory enterprise trying to accomplish?" This Article touches on both these themes before concluding that some of the gaps in the current regulatory framework for DIYbio are appropriate and ought to be preserved.

\section{Focusing the Discussion}

Before turning to those questions, it is useful to clarify how the terms "citizen science," "DIY genomics," and "DIYbio" are used in this article. Discussions of how to regulate this movement often assume that people participating in it are scientifically unsophisticated and require close supervision as a result. An excellent article by Andrea Wiggins and John Wilbanks acknowledges that citizen science comprises diverse activities that employ a range of scientific methods and different modes of participant involvement. ${ }^{3}$ They define citizen science as "a range of participatory models for involving non-professionals as collaborators in scientific research." 4 However, the available empirical evidence does not always support the narrative that citizen

\footnotetext{
${ }^{1}$ See generally NAT'L ACAdEMIES ScI., EngINEERING, \& MED., PrEPARING FOR Future Products OF BIOTECHNOLOGY 67-102 (2017) (ebook) [hereinafter NASEM REPORT] (summarizing the current U.S. regulatory framework for biotechnology products).

${ }^{2} I d$. at 27-58 (describing trends, including DIYbio, that threaten to disrupt traditional biotechnology oversight mechanisms).

${ }^{3}$ Andrea Wiggins \& John Wilbanks, The Rise of Citizen Science in Health and Biomedical Research, 19 AM. J. BioETHICS, n. 8, 2019, at 3.

${ }^{4}$ Id. (emphasis added).
} 
scientists are non-professionals or scientifically naïve; many are scientists employed in academic, corporate, or governmental laboratories who pursue DIYbio as an avocation, but one they are wellqualified to pursue. ${ }^{5}$

Professor Lisa Ikemoto explores various narratives of DIYbio. ${ }^{6}$ There are expressly political narratives that sound in democratization of science, and nostalgic accounts that portray DIYbio as returning science to non-commercial aims and an open-sharing ethos that allegedly was lost after passage of the Bayh-Dole Amendments in the early 1980s. ${ }^{7}$ She draws on an 1893 paper by Frederick Jackson Turner ${ }^{8}$ to suggest an intriguing alternative: DIYbio serves as a frontier of institutional science, an outlet or safety valve that provides an "unconstrained space" to pursue inquires that, although valid and potentially important, are not being pursued at the nation's traditional scientific institutions. ${ }^{9}$ The reasons might include, for example, ethical misgivings about the research or the lack of traditional sources of research funding, such as National Institutes of Health (NIH) grants.

Tinkering with the human genome involves risks that are poorly understood and difficult to manage at this time. These include the risk of unintended off-target effects that might damage regions of the genome that were not the focus of research, and a risk of unintentionally promoting cancer while attempting to introduce a beneficial change. ${ }^{10}$ Traditional research ethics, and the traditional research institutions that implement those ethics, might view these risks as ethically justified under certain circumstances and for certain narrow research aims such as trying to develop therapies for serious or deadly health conditions that lack good therapeutic options. The risks are harder to justify for many other research aims, such as cosmetic enhancement. Many of these other research aims do offer potential benefits; it would be highly beneficial to have a therapy that could keep us all looking 25 years old forever. Unfortunately, many beneficial lines of research are ethically problematic or fall outside the funding priorities of the traditional research enterprise. Professor Ikemoto's "frontier" theory portrays citizen science and DIYbio as a needed space for scientists to pursue these beneficial aims. ${ }^{11}$

Doing so may require citizen scientists to internalize research risks by experimenting on themselves. It might be argued that self-experimentation is, in fact, ethically superior to involving hapless research participants in projects that are potentially beneficial but ethically questionable. ${ }^{12}$ At times, medical self-experimentation has spurred important advances in biomedicine. Allen Weisse surveyed 465 instances of medical self-experimentation after $1800 .{ }^{13} \mathrm{He}$ found that twelve Nobel Prize winners between 1903 and 2005 engaged, at one time or another, in biomedical self-

\footnotetext{
${ }^{5}$ Lisa C. Ikemoto, DIY Bio: Hacking Life in Biotech's Backyard, 51 U.C. DAVIS L. REV. 539, 541, 546 (2017).

${ }^{6} \mathrm{Id}$. at $548-52$.

${ }^{7}$ Id. at $550-51$.

${ }^{8}$ The Significance of the Frontier in American History, NAT'L HuMAN. CTR. (May 2005), http://nationalhumanitiescenter.org/pds/gilded/empire/text1/turner.pdf. (quoting speech by Frederick Jackson Turner to American Historical Association in Chicago July 12, 1893).

${ }^{9}$ Ikemoto, supra note 5, at 552.

${ }^{10}$ See, e.g., Erika Check, Second Cancer Case Halts Gene-Therapy Trials, 421 NATURE 305, 305 (2003) (reporting that a gene-therapy trial to address severe combined immunodeficiency disease (SCID, or "bubble boy disease") in children had been halted after some of the participants developed leukemia, raising concerns that the research had inadvertently damaged a tumor-suppressor gene).

${ }^{11}$ Ikemoto, supra note 5, at 552.

${ }_{12}$ Barbara J. Evans, Parsing the Line Between Professional and Citizen Science, 19 AM. J. BIOETHICS 15, 15 (2019).

${ }^{13}$ Allen B. Weisse, Self-Experimentation and its Role in Medical Research, 39 TEX. HEART INST. J. 51, 51-54 (2012).
} 
experimentation and, in seven cases, the Nobel Prize was for the work that relied on selfexperimentation. ${ }^{14}$

While "legitimate" scientists generally favor other methodologies today, selfexperimentation was common in the United States until the mid-20 $0^{\text {th }}$ century. ${ }^{15}$ Small research cohorts, including cohorts of one person, could shed light on important research questions of that era, when infectious diseases, vaccines, and anesthesia were topics of great scientific concern. ${ }^{16}$ In the research ethics of that day, some scientists considered it unethical to expose other people to research risks, as opposed to taking the risks oneself. ${ }^{17}$

In the last half of the $20^{\text {th }}$ century, the nation's disease burden shifted and new research methodologies, such as randomized, controlled clinical trials, emerged. These developments called for ever-larger cohorts of research participants to answer contemporary research questions. Research ethicists responded by enunciating modern standards, such as the Common Rule, ${ }^{18}$ that conceive research as something scientists do to other people. The ethics of self-experimentation ceased to command much attention. Yet in some respects, gene-editing research resembles the early vaccine research of the $19^{\text {th }}$ century as much as it resembles a late $20^{\text {th }}$ century large-scale clinical trial. Self-experimentation may, once again, be a useful research methodology in certain contexts. A fresh look at ethical and regulatory principles, and how to promote compliance with them, may be warranted.

This article accepts Professor Ikemoto's view of DIYbio as a frontier for scientific discovery but develops an additional point: DIYbio is also a frontier for business model innovation. Christenson, Grossman, and Hwang, in their excellent study of disruptive innovation in health care, remark that new technologies are, at most, enablers of transformative change that can make a real difference in people's lives. ${ }^{19}$ Advances in genomics will be necessary, but not sufficient, to transform the quality of health care. There also must be business model innovation that profitably delivers new technologies in ways that are affordable and accessible to consumers, and new value networks, which are commercial infrastructure in which the various players "exert disruptive, mutually reinforcing economic models." 20

Economic and regulatory factors create a significant risk that scientific advances in genomics may fail to improve the lives of patients and consumers who might benefit. Today's legacy regulatory frameworks were designed for an industry structure and business models that

${ }^{14} I d$.

${ }^{15} I d$.

${ }^{16} I d$.

${ }^{17} I d$. at 545 (citing SAUl Benison, Tom Rivers: Reflections ON A Life IN MEDICINE AND SCIENCE 54 M.I.T. Press 1967)).

1845 C.F.R. pt. 46, subpt. A (2018).

${ }^{19}$ CLAyton M. Christenson ET AL., The InNOVATOR's PRESCRIPTION: A DisRUPTIVE SOlution For HeAlth CARE (2017).

${ }^{20} I d$. 
prevailed in the latter half of the $20^{\text {th }}$ century, the heyday of non-personalized blockbuster medical products, for which high regulatory costs could be spread across large numbers of consumers. These same regulatory processes, when applied to modern gene therapies for orphan or ultraorphan (extremely rare) conditions, deliver safe and effective therapies at eye-popping prices. ${ }^{21}$ Glybera, a gene therapy to treat a rare blood disorder, came to market in the EU at a cost of 1.1 million Euros for a course of treatment, only to be withdrawn after only one patient managed to surmount the steep barriers to insurance reimbursement. ${ }^{22}$ Gene therapies promise to restore sight to the blind but only if the blind, who experience above-average rates of poverty, unemployment, and noninsurance, ${ }^{23}$ can self-pay as much as a million dollars per eye to see again. No matter how great the science is, this is not a workable business model. Shaking up yesterday's business models may ultimately be the most useful contribution DIYbio and citizen science make.

This article explores the challenge of regulating of DIYbio and citizen science generally, but then zooms in on genomic self-experimentation as a potential focus of regulatory concern. To keep matters in perspective, DIYbio today mostly involves fairly basic activities such as testing oneself to detect the presence or absence of specific genetic variants; extracting DNA; purifying proteins; or genetically engineering bacteria, yeast, cells, or plants. ${ }^{24}$ Despite isolated reports of people injecting themselves with gene-editing chemicals, ${ }^{25}$ there is currently no rush of people trying to edit their own genomes. ${ }^{26}$ While not a focus of DIYbio activities today, such attempts are foreseeable and do warrant some discussion, mainly to probe what the goals of regulation ought to be.

\footnotetext{
${ }^{21}$ Gregory Daniel et al., Advancing Gene Therapies and Curative Health Care Through Value-Based Payment Reform, HeALTH AFF. BLOG (Oct. 30, 2017), https://www.healthaffairs.org/do/10.1377/hblog20171027.83602/full/. ${ }^{22}$ Grace Marsden et Al., InSt. FOR Clinical \& ECON. ReV., Gene Therapy: Understanding the SCIENCE, ASSESSING THE EVIDENCE, AND PAYING FOR VALUE 19-20, 26 (2017).

${ }^{23}$ See Blindness Statistics, NAT'L FED'N BLIND, https://www.nfb.org/resources/blindness-statistics (last visited Apr. 3, 2020) (citing statistics on the economic impact of blindness); see also Diana M. Zuckerman, NAT'L CTR. FOR POL'y RES. FOR WOMEN \& FAMILIES, BLIND ADULTS IN AMERICA: THEIR LIVES AND CHALLENGES (2004) (reporting U.S. statistics).

${ }^{24}$ Daniel Grushinin et Al., Seven Myths and Realities About Do-IT-Yourself Biology 11 (Woodrow Wilson Int'l Ctr. for Scholars 2013).

${ }^{25}$ Molly Campbell, Meet Josiah Zayner, The Biohacker Next Door, TECH. NeTworks (June 21, 2019), https://www.technologynetworks.com/genomics/articles/meet-josiah-zayner-the-biohacker-next-door-320964.

${ }^{26}$ See GRUSHKIN ET AL., supra note 24, at 1.

${ }^{27}$ See NASEM REPORT, supra note 1, at 69-70 (discussing the role of NIH guidelines in governance of both public and privately funded genomic research).

${ }^{28} I d$.
} 


\section{Twentieth-Century Regulation for the Twenty-First Century}

The United States entered the $21^{\text {st }}$ century with legacy regulations designed in the $20^{\text {th }}$ century. In those days, creation of nonmarket and public goods, such as upstream basic research to discover new therapies, received public support through entities like the NIH which, through the power of its immense purse strings, elicited compliance with important research, ethical, and biosafety norms. ${ }^{27}$ These same norms were embraced by many commercial research organizations that were not, legally speaking, obliged to follow them. ${ }^{28}$ In a competitive environment for research funding, both public and private funders implemented rigorous review processes that deterred the pursuit of "junk" science.

Medical product manufacturers, shielded by patents and high regulatory barriers to entry, attained the scale and strong balance sheets that it takes to bear the costs of generating evidence to support premarket regulatory review of their products. ${ }^{29}$ The large scale (and relatively small number) of manufacturers made close regulatory scrutiny feasible and cost-effective. ${ }^{30}$ Healthcare providers were generally convincing in the role of learned intermediaries. They incorporated patient-specific data into decisions about how to treat real patients using products only shown safe and effective for the average clinical trial participant, and they dispensed off-label prescriptions to treat, or at least mollify, patients whose maladies had no approved remedies. All together, these players delivered fairly good health care to many patients, with trial lawyers waiting in the wings to pursue remedies if their efforts fell short of this goal. That was the orderly world of $20^{\text {th }}$-century regulation - a world that is now being disrupted.

By 2015, the Obama Administration foresaw this problem and began efforts to update the United States' framework for regulating biotechnology. These efforts included a study of new types of biotechnology products expected to become available over the next decade and the adequacy of existing regulations to ensure consumer and patient safety and address environmental and other hazards they might entail. The U.S. National Academies of Science, Engineering, and Medicine ("NASEM" or the "National Academies") performed that study and published it in $2017 .{ }^{31}$ The study presumed that, within the ten-year time horizon of the study, it would not be possible to implement major regulatory reforms because of the time required to draft new legislation, enact it, and put new regulations in place. ${ }^{32}$ This implied that the new products would have to be regulated using the Coordinated Framework for Regulation of Biotechnology

\footnotetext{
${ }^{29}$ Inst. Med., The Future OF Drug SAfety: Promoting And Protecting the Health OF THe Public 197 (Alina Baciu et al. eds., Nat'l Academies Press 2007).

${ }^{30}$ See Kellen Zale, When Everything is Small: The Regulatory Challenge of Scale in Sharing Economy, 53 SAN DIEGO L. REV. 949, 964-66 (2016) (reviewing literature addressing the relationship between the scale of regulated enterprises and the efficiency and cost-effectiveness of regulatory efforts).

${ }^{31}$ NASEM REPORT, supra note 1 , at $70-71$.

${ }^{32} I d$. at 68.

${ }^{33}$ Coordinated Framework for Regulation of Biotechnology, 51 Fed. Reg. 23302 (June 26, 1986).

${ }^{34}$ NASEM REPORT, supra note 1 , at 70.

${ }^{35} \mathrm{Id}$.

${ }^{36}$ Coordinated Framework for Regulation of Biotechnology, 51 Fed. Reg. at 23302.
} 
(Coordinated Framework), which is the scheme of federal oversight conceived in response to advances in recombinant DNA technology back in the 1980s. ${ }^{33}$ Those advances raised concern that there would be a large number of new recombinant DNA products for which existing regulatory frameworks might prove inadequate.

Congress toyed with the idea of enacting special biotechnology legislation, but ultimately did not do so. ${ }^{34}$ In 1984, a Working Group on Biotechnology working under the White House Cabinet Council on Natural Resources and the Environment recommended that existing federal agencies - such as the Environmental Protection Agency (EPA), the Food and Drug Administration (FDA), and the U.S. Department of Agriculture (USDA) - should regulate new biotechnology products using the statutory authorities they already had. ${ }^{35}$ In 1986, this approach was formalized in the Coordinated Framework, which clarifies how the various agencies will share responsibilities. ${ }^{36}$

The Coordinated Framework grants no new powers to the agencies. Each has only the powers Congress already granted to it in its enabling statutes. Thus, the FDA uses the authorities it has under the federal Food, Drug, and Cosmetic Act (FFDCA) ${ }^{37}$ and the Public Health Service Act ("PHSA"); the EPA regulates under its existing statutes, such as the Toxic Substances Control Act; and the USDA implements the Plant Protection Act, the Federal Meat Inspection Act, and other statutes. ${ }^{38}$ The Coordinated Framework was updated in 1992 and at the end of the Obama Administration in January 2017, although this latter update expressly declined to address biotechnologies, like human genome editing, that FDA regulates as medical products. ${ }^{39}$ The FDA

\footnotetext{
${ }^{37}$ Federal Food, Drug, and Cosmetic Act, Pub. L. No. 75-717, 52 Stat. 1040 (1938) (codified as amended at 21 U.S.C $\$ \$ 301-397$ (1994 \& Supp. II 1997)).

38 See OfFice of Sci. TeCh. PoL'y, EXeC. OfFice of the President, An UPdATE to the CoORdinAted FRAMEWORK FOR BIOTECHNOLOGY PRODUCTS 9 (2017) (providing a list of key statutes).

${ }^{39}$ Id.; Planned Introductions of Biotechnology Products Into the Environment, 57 Fed. Reg. 6753-62 (Feb. 27, 1992).

${ }^{40}$ Peter Hutt et Al., Food and Drug Law: Cases And Materials 1123 (W. Acad. Publ'g 4th ed. 2014).

${ }^{41}$ NASEM REPORT, supra note 1, at 11.

${ }^{42}$ Id. at 10.
} 
already had efforts underway, as of 2017, to set policies for those products, so the revised Coordinated Framework deferred to the FDA.

The Coordinated Framework is criticized as a loose collection of antiquated statutes, none of which was designed for the biotechnology products of today. To some degree, this is a fair criticism. Today, the FDA is tasked with regulating the latest human gene-editing products using drug authorities rooted in the 1938 FFDCA and the even older biologics authorities of the PHSA, which harken back to the age when diphtheria antitoxin and smallpox vaccine were the latest technologies. ${ }^{40}$ The National Academies, in their 2017 study, expressed concern that new products might fall through gaps in regulatory jurisdiction and that the regulatory powers these old statutes confer are not always what the agencies need to regulate effectively. ${ }^{41}$ For example, a power to require brief, premarket studies does not answer long-term safety questions about gene-editing products, which might require lifelong monitoring to assess whether they elevate patients' cancer risks. Another concern was that the sheer pace, volume, and complexity of current innovations could threaten to overwhelm the agencies' existing regulatory capacity. ${ }^{42}$

Despite these concerns, the Coordinated Framework has worked fairly well over the past three decades. Congress used broad language when defining the products - for example, "drug," "biological product," "device," "food," "pesticide," "plant pest," and "chemical" - that the FDA, EPA, and USDA are authorized to regulate. ${ }^{43}$ The agencies have significant - although not unlimited $^{44}$ - discretion to determine what fits in these definitions. The FDA, in particular, has a long history of construing novel products as fitting within its available jurisdictional categories, and courts frequently defer to the agency's determinations. A classic example is a 1969 case in which the Supreme Court backed the FDA in deeming a product to be a drug, even though the product undoubtedly would be a device under today's standards, because the FDA's determination was "consistent with the FFDCA's overriding purpose of protecting the public health." 45 There is little doubt that many of the products used in DIY genomics and citizen science are of the sort that the FDA and its sister agencies are authorized to regulate under the Coordinated Framework.

\section{Strains in the Coordinated Framework}

If the Coordinated Framework is currently under stress, this is not because of the technologies and products that modern biotechnology is producing. There are a few notable gaps in regulatory coverage, but the technologies and products are, for the most part, well within the scope of what the Coordinated Framework was designed to regulate. Instead, the major strain

\footnotetext{
${ }^{43}$ See id. at 209-12 (listing some of the statutory definitions).

44 Nat'l Nutritional Foods v. Matthews, 557 F.2d 325, 336 (2d Cir. 1977) (concluding that proposed FDA regulations that treated vitamins $\mathrm{A}$ and $\mathrm{D}$ as drugs, instead of foods, were invalid as "arbitrary and capricious and not in accordance with law.").

${ }^{45}$ United States v. Bacto-Unidisk, 374 U.S. 784, 798 (1969).
} 
relates to new business models for delivering biotechnology products and services. "The very concept of 'regulation,' as developed and practiced under the web of old statutes the Coordinated Framework rests on, fails unless there are suitable entities to regulate." 46 The Coordinated Framework and its underlying statutes presume a $20^{\text {th }}$-century biotechnology industry structure that has - and will continue to have - ongoing vitality. However, the traditional players increasingly will be competing alongside new players with new business models, some of which can evade regulation under current statutes.

Twentieth-century biotechnology regulations direct the regulator's attention to "product developers," mainly conceived as "U.S. and international corporations, research organizations, small- and medium-sized enterprises" that are involved in commercial development, manufacturing, or distribution of biotechnology products. ${ }^{47}$ The regulator stands as an intermediary between these commercial entities and "the public and society," whose safety the regulator is empowered to protect. ${ }^{48}$ Members of the public occasionally fall under these regulations, for example, if Grandma launches a website offering her traditional home remedy for commercial sale to the public as a cure for arthritis. In general, however, members of the public play a passive role, simply consuming the products that corporate product developers design and manufacture, usually with little public input or involvement. Individuals often engage in "[u]nregulated domestic production and use"-for example, preparing a home remedy for themselves instead of buying a manufactured drug-but regulators use their discretion and generally avoid regulating these activities so long as they are small in scale and have personal, non-commercial aims. ${ }^{49}$

The National Academies' 2017 study noted several trends that are disrupting this traditional regulatory landscape. ${ }^{50}$ An obvious example is DIYbio, carried out in community laboratories or in people's homes. Another is non-traditional funding sources for research, including crowdsourced funding for biotech research and development projects. The result is that important research activities now are occurring beyond the reach of the ethical and safety norms traditionally tied to public research funding and corporate research policies that often embrace those same norms. ${ }^{51}$ There are new commercial manufacturers operating in decentralized formats or at a smaller scale than the larger product developers of the past. These smaller players sometimes lack the well-staffed regulatory compliance departments with which regulators have traditionally interfaced, and they may lack the large retained earnings that product developers traditionally used to fund studies to develop the evidence on which regulators rely when approving new products. "A key, new element associated with the development of biotechnology products in the United States is the multiplicity of different players that intersect and collaborate in flexible but robust entrepreneurial ecosystems." 53

These changes are spawning new business models: First, there are new business-tobusiness models. These include, for example, contractors that offer bioinformatics services to

\footnotetext{
${ }^{46}$ Barbara J. Evans, Programming Our Genomes, Programming Ourselves: The Moral and Regulatory Challenge of Regulating Do-IT-Yourself Gene Editing, In Consuming GenOmics (I. Glenn Cohen et al. eds., forthcoming 2021).

${ }^{47}$ See NASEM REPORT, supra note 1, at 20 fig.1-1 (portraying this relationship).

${ }^{48} \mathrm{Id}$.

${ }^{49} \mathrm{Id}$.

${ }^{50} I d$. at 27.

${ }^{51} \mathrm{Id}$. at 85 .

${ }^{52} I d$. at 33-35.

${ }^{53} I d$. at 36 .
} 
existing product developers and laboratories, or laboratories that make DNA fragments and other chemicals to order for other product developers. ${ }^{54}$ Second, there are new business-to-consumer models. ${ }^{55}$ A good example is DTC genetic testing services. Third, there are new consumer-toconsumer models. ${ }^{56}$ These include individuals making products for commercial sale to other members of the public. However, they also include individuals providing services, such as creating a community laboratory that others can use to make their own products, or publishing instructions to guide others in their own DIYbio activities. The fourth model blurs the roles of producer and consumer, as when practitioners of DIYbio make products for their own enjoyment or consumption. ${ }^{57}$

The end products of these new arrangements often are of a sort that the FDA and its sister agencies traditionally have regulated. However, these new business models may cause some or all of the production chain to evade regulatory oversight. For example, the FDA can regulate an entity that manufactures or distributes a product and does so with the intent it be used to diagnose, treat, or prevent a disease or health condition. ${ }^{58} \mathrm{~A}$ business-to-business laboratory that synthesizes DNA fragments or chemicals is manufacturing a product and seemingly would be subject to FDA regulation, because the FDA's definition of a "drug" includes "a component" of a finished drug product. ${ }^{59}$ In contrast, a business-to-business provider of bioinformatics analysis is supplying a service, rather than a product, and seemingly escapes FDA's jurisdiction. Even if the software helps a drug manufacturer screen the safety of its finished drug, the software is not itself a drug component. The FDA can regulate software as a medical device (SAMD), standalone software that is intended to diagnose, treat, or prevent disease. ${ }^{60}$ However, the bioinformatics software in this example is not itself intended for use in treating patients; it is intended for use in designing a drug, and the drug is the product that will treat the patient. This software, therefore, does not appear to qualify as SAMD.

The new business-to-consumer models present similar issues. The FDA has already asserted jurisdiction over several DTC test providers, such as 23andMe, whose advertising or test reports suggested they intended for their tests to be used in diagnosing, treating, or preventing disease. ${ }^{61}$ Other DTC providers, however, offer data-only services that simply report which genetic variants the person has, without making any claims or interpretive statements about how those variants might affect the person's health. FDA officials have indicated in the past that they do not view data-only tests as medical devices that the agency can regulate. ${ }^{62}$ Consumers can then enter their data-only results into various online software tools or submit them to stand-alone genetic interpretation services that help consumers understand how their variants might affect their health. It is not clear that the FDA can regulate those tools and services, because the providers are

\footnotetext{
${ }^{54}$ Id. at 37 .

${ }^{55} I d$.

${ }^{56} \mathrm{Id}$. at 37.

57 Id. at 36.

${ }^{58}$ See, e.g., 21 U.S.C. $\$ 321(\mathrm{~g})(1)$, (h) (2018)..

${ }^{59} I d . \S 32 \lg (1)(4)$.

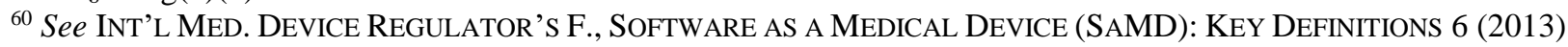

(defining software as a medical device).

6121 U.S.C. $\S 321(\mathrm{~h})$.

${ }^{62}$ Dan Vorhaus et al., DTC Testing and the FDA: Is There an End in Sight to the Regulatory Uncertainty?, GENOMES UNZIPPED (June 16, 2011), http://genomesunzipped.org/2011/06/dtc-genetic-testing-and-the-fda-is-therean-end-in-sight-to-the-regulatory-uncertainty.php\#more-3681.
} 
distributing informational or professional services, without manufacturing or performing any tests. $^{63}$

Consumer-to-consumer business models present similar ambiguities. An individual who uses DIYbio to synthesize a product for others is a manufacturer, as far as the FDA is concerned, and that is true whether the product is sold or distributed gratis. If the individual intends for the product to be used as a dietary supplement, food additive, or medical food (e.g., a genetically enhanced yogurt culture) or as a cosmetic or drug (e.g., an anti-aging potion), the FDA can regulate it, assuming the agency finds out the product exists. ${ }^{64}$ The DIY practitioner could, however, evade FDA jurisdiction if it refrained from manufacturing the product and instead published instructions on how to make the product or established a community laboratory that customers can use, for a fee, to make their own supplies. These latter activities are in the nature of services, and writing "how-to" books often enjoys First Amendment protection. DIYbio products can be delivered in various ways that may, or may not, be subject to regulation.

The fourth business model - producing biotechnology products for one's own use presents special regulatory issues discussed later in this article. DIYbio projects are extremely diverse. Many are unrelated to health and raise few, if any, regulatory concerns. Good examples are projects to develop genetic tests to identify which neighborhood dog is defiling one's yard, or to detect whether restaurants are correctly advertising the species of fish in their sushi. ${ }^{65}$ In contrast, other DIYbio efforts - such as a diabetic's attempt to make low-cost insulin, or a gardener's attempt to engineer plants for open release into the environment - do raise important questions about the capacity of Coordinated Framework agencies to provide adequate oversight. ${ }^{66}$

The new business models create challenges that the National Academies described in their 2017 study: Today's biotechnology platforms - that is, products used to make other biotechnology products - have altered the relationship between "wet-lab" and "dry-lab" functions within the product supply chain. ${ }^{67}$ Wet-lab products are physical things like DNA/RNA, cells, enzymes, vectors, and sequencing prep kits, whereas dry-lab products are things like computer-aided design software or bioinformatics tools which, when offered on a stand-alone basis, are in the nature of services. ${ }^{68}$ The new platforms make it possible to redesign the workflows required to make new biotechnology products. The result is new business models, some of which may fall outside the jurisdiction of traditional safety and environmental regulators like the FDA, EPA, and USDA. The entity that manufactures a new product may be different from the entity that forms the intent for how it will be used. This can leave gaps in regulatory coverage, even when the finished product is of a sort that the public expects is receiving governmental oversight. Even when regulators do have jurisdiction, the presence of new and unconventional players creates novel challenges. For example, agencies trying to monitor DIYbio to address bioterrorism risks have embraced a lighthanded approach because of concerns that aggressive regulatory enforcement might drive these activities underground, making oversight even more difficult than it already is. ${ }^{69}$

\section{The Practical Challenge of Regulating Small, DIY Producers}

${ }^{63}$ Gail H. Javitt \& Katherine Strong Carner, Regulation of Next Generation Sequencing, 42 J.L. MED. \& ETHICS 9 , 9-21 (2014).

${ }^{64} 21$ U.S.C. $\$ \S 321(\mathrm{ff}), 321(\mathrm{~s}), 360 \mathrm{ee}(\mathrm{b})(3), 321(\mathrm{i}), 321(\mathrm{~g})(1)$.

${ }^{65}$ Ikemoto, supra note 5, at 543.

${ }^{66}$ Id.; see also NASEM REPORT, supra note 1, at 46-47.

${ }^{67}$ NASEM REPORT, supra note 1 , at 5.

${ }^{68} \mathrm{Id}$.

${ }^{69}$ Id. at 73 . 
Individuals, working at home or in community laboratories, now are able to manufacture products that once would have required a large organization to assemble. Individuals have access to sophisticated software tools to help them design strands of DNA to perform particular functions, such as enabling a cell to detect a specific chemical stimulus and react to it. ${ }^{70}$ Using these tools, individuals can design strands of DNA or guide RNAs for CRISPR editing systems that can make cells have new characteristics. ${ }^{71}$ Standard biological parts, such as off-the-shelf DNA strands to perform particular functions, are available for purchase, and contract laboratories can synthesize customized DNA and RNA in response to a customer's order. ${ }^{72}$ Even individuals with "no special knowledge of genetic engineering" can manipulate plant and animal genomes. ${ }^{73}$

The providers of goods and services with which the individual does business may or may not be subject to oversight by Coordinated Framework agencies like the FDA. A vendor whose software can design DNA molecules is not involved in manufacturing any physical product, and may not form any particular intent with respect to how the molecules will be used. The contract laboratory that manufactures DNA sequences and other molecules may be unaware of their ultimate intended use. Many of these products lend themselves to a wide variety of uses, so that it is not possible to infer an intent for clinical use from the mere fact that an order was placed and filled. The product might end up in a hobby project to modify an orchid plant, or in a preclinical research use, or in an attempt to modify a human genome for therapeutic purposes. The Federal Select Agent Program administered by the U.S. Department of Agriculture and the Centers for Disease Control recognizes a small number (roughly 65) of biological agents that have narrow uses and a high potential for harm, such that any shipment of these chemicals triggers regulatory oversight. ${ }^{74}$ Outside this small set of biological agents, which include things like the Ebola virus, most of the things laboratories ship cannot be presumed to have any particular intended use. FDA seemingly has no basis to infer that the contract laboratory intended for its creation to be used as a medical product.

This leaves the individual DIYbio practitioner as a potential target for regulation, but regulating these small players poses a number of logistical and practical challenges, even when an agency like the FDA theoretically has jurisdiction to do so. Similar challenges occur in regulating participants in the sharing economy, which includes people who drive for ride-hailing services like Uber and Lyft or who rent their homes through platforms like Airbnb. " $[S]$ cale is a defining feature and fundamental challenge of the sharing economy." 76 The nation's legacy regulatory frameworks are designed to regulate a discrete number of large, commercial product developers. The sharing economy includes three-way transactions among a massive number of small providers, consumers, and platforms that bring them together.

The sharing economy is large in the aggregate, with it estimated that about half of Americans participate either as producers or consumers, but missing are the large providers of

\footnotetext{
${ }^{70}$ Anne Trafton, A Programming Language for Living Cells: New Language Lets Researchers Design Novel Biological Circuits, MIT NEWs (Mar. 31, 2016) http://news.mit.edu/2016/programming-language-living-cellsbacteria-0331.

${ }^{71}$ NASEM REPORT, supra note 1 , at 28-33.

${ }^{72} I d$.

73 Trafton, supra note 70.

74 NASEM REPORT, supra note 1, at 73.

${ }^{75}$ See generally Zale, supra note 30.

${ }^{76} \mathrm{Id}$. at 950 .
} 
goods and services that were the focus of $20^{\text {th }}$ century regulatory schemes. ${ }^{77}$ Zale points out that $20^{\text {th }}$ century regulators could order hotels to implement consumer safety measures and to accommodate disabled guests; the hotels were at known locations that regulators could easily inspect, and the hotels had sufficient revenue to absorb the regulatory compliance costs. The same is not true as hotels are replaced by millions of individual homeowners renting a room through home-sharing services like Airbnb; "when everything is small, the regulatory challenge is immense." ${ }^{78}$ In some cases, $20^{\text {th }}$ century regulations expressly exclude small actors from regulation, as seen in some labor laws and workplace safety regulations. ${ }^{79}$ Even when regulations do not expressly provide breaks for small suppliers, regulators have often used their discretion to avoid regulating them.

Zale explores traditional and emerging rationales for non-regulation of small players. ${ }^{80}$ One is the de minimis nature of individual, small-scale activities, which may have only a minor link to interstate commerce. It is thought harsh to place the heavy burdens and costs of regulatory compliance on small players, and there are concerns about the feasibility and costs of having regulatory agencies scale up to oversee activities at thousands or millions of diffuse sites around the nation. Regulating individuals triggers concerns about personal privacy, and regulators could face constitutional barriers to invading people's homes. An emerging issue is that the information regulators need to detect and regulate individual players may be held by third parties, such as the platforms that broker individual transactions in the sharing economy. Regulators might lack jurisdiction to force the platforms to disclose information, if the platforms are not themselves involved in the activities (such as providing lodging or ride services) that trigger regulatory jurisdiction. Moreover, the platforms sometimes are subject to state privacy laws or business policies that force them to protect individuals' privacy. Finally, there is wide skepticism that coercive, top-down regulation would be effective. Social norms or other community-based mechanisms might offer better ways to promote good conduct at the level of individuals.

There do not appear to be express statutory limits on the FDA's ability to regulate individual DIYbio practitioners that become producers of medical products. The FDA's statutes do not vary regulatory requirements based on the size of the manufacturer, although there is some easing of requirements based on the market size of the product. Thus, the FDA's device statute eases regulatory burdens for custom devices, such as orthotic devices to help with foot pain and orthodontic appliances, which are customized for each patient. ${ }^{81}$ Custom devices are sold in quantities of five or fewer devices per year, although the companies that make them often are large-scale operations serving large numbers of customers. Drugs and biological products designed to treat rare diseases can obtain orphan drug designation, but the scale involved is still quite a large market serving up to 200,000 patients per year. ${ }^{82}$ The companies serving these niche markets may be large pharmaceutical companies in their own right, for which the orphan drug is only one of many product offerings.

The FDA's traditional non-regulation of individual producers reflects an exercise of enforcement discretion, rather than a jurisdictional limitation. A mother who makes chicken soup

\footnotetext{
${ }^{77} I d$. at 952,955 n.6.

${ }^{78} \mathrm{Id}$. at 950.

${ }^{79}$ See, e.g., Small Business Requirements, U.S. EQUAL EMP'T OPPORTUNITY COMM’N, https://www.eeoc.gov/employers/smallbusiness/requirements.cfm (last visited Apr. 13, 2020); see also Zale, supra note 30 , at 950 .

${ }^{80}$ Zale, supra note 30 , at 955.

8121 U.S.C. $\$ 360 j$ (b) (2018).

8221 C.F.R. $\$ 316.20$ (b)(6) (2019).
} 
for her family or friends with claims that it will cure their colds is, technically, a drug manufacturer. Mom intends for the soup to be used for "the diagnosis, cure, mitigation, treatment, or prevention of" disease. ${ }^{83}$ So long as Mom's soup distribution remains personal and non-commercial, the FDA generally looks the other way. If, however, mom scales up her operations and starts marketing soup commercially with curative claims, the agency could change course and send mom a warning letter.

Zale maintains that twentieth-century regulations functioned well precisely because FDA and other regulators recognized a distinction between commercial and large-scale activities that warranted regulation, and personal or small-scale activities that deserved leniency. ${ }^{84}$ DIYbio is eroding these crucial distinctions. "Small-scale activities that once fit criteria for light or no regulation" can attain aggregate volumes that threaten to marginalize consumer-safety regulators, if they continue to focus only on traditional, large-scale players. ${ }^{85}$

There have been many calls for safety regulators to step up their oversight of DIY genomics, yet the Coordinated Framework leaves them ill-equipped for the task. The contract laboratories and informatics service providers that enable individual production may themselves escape FDA oversight. The FDA technically has jurisdiction to regulate individual DIYbio producers that position their offerings as medical products. Yet the agency's available regulatory tools, such as inspections, can be constitutionally cumbersome when the inspected facility is a person's home. Traditional product developers, by obtaining FDA clearance or approval to market a product, effectively consent to inspection of their facilities; refusing to admit an FDA inspector is a prohibited act that can cause the product to become adulterated or misbranded. ${ }^{86}$ Yet if FDA inspectors show up at my home, they had better show me a warrant. ${ }^{87}$ This, of course, presumes the FDA finds out I am cooking up genetically modified things in my kitchen. What if individual DIYbio producers forget to comply with the FDA's registration and listing regulations? ${ }^{88}$ Those regulations require medical product manufacturers to make themselves known to the FDA so that the agency will know where to inspect. The agency staffing and budgets necessary to enforce FDA regulations against large numbers of individual DIYbio producers could make regulatory enforcement infeasible, if DIYbio catches on and large numbers of Americans start to do it.

\section{Moral Problems in Regulating the Individual Producer/Consumer}

The practical regulatory challenges just described apply to individual DIYbio producers, whether they are making products for others under a consumer-to-consumer business model or developing products for their own enjoyment and use. This latter scenario, in which the individual doubles as producer and consumer, poses an additional complexity concerning the goals of consumer safety regulations. If an adult wishes to edit her genome to alter her body in ways that many people would regard as harmful, is it really the FDA's role to stop her? By analogy, the FDA has no jurisdiction to stop people from covering their bodies with tattoos, although FDA is authorized to regulate the needles and ink to ensure they are sanitary and non-toxic. Congress

${ }^{83} 21$ U.S.C. $\$ 321(\mathrm{~g})(1)$.

${ }^{84}$ Zale, supra note 30 , at 950.

${ }^{85} \mathrm{Id}$. at $956-57$.

${ }^{86} 21$ U.S.C. $§ 331(f)$.

${ }^{87}$ See U.S. CONST., amend. IV.

${ }^{88}$ See, e.g., How to Register and List, U.S. FoOD \& DRUG ADMIN. (Aug. 23, 2018), https://www.fda.gov/medicaldevices/device-registration-and-listing/how-register-and-list (explaining FDA's registration and listing requirements for device manufacturers). 
authorizes the FDA to regulate producers and distributors of medical products, but not to regulate consumers. DIYbio interjects a new self-service business model in which the individual is both producer and consumer. This creates a risk that the FDA's role in regulating producers might blur into inappropriate regulation of consumers. How far can governments go in banning self-harming or personally risky conduct without infringing on citizens' autonomy?

Joel Feinberg's Harm to Self, explores this question, identifying ten principles that might justify governmental interventions to limit harms that people do to themselves, to others, or to the public at large. ${ }^{89}$ Of these ten principles, several are helpful to this discussion:

- The Harm Principle refers to the concept that it is appropriate for the government to regulate an actor in order to avoid harms to persons other than the actor. ${ }^{90}$ Feinberg identifies this as the principle animating United States' Food and Drug laws. ${ }^{91}$ The FDA regulates medical product manufacturers and distributors to keep them from offering products that might injure consumers. ${ }^{92}$ This principle also could encompass, for example, a regulation that prevents people of childbearing age from editing their own genomes in order to prevent possible harms to their future offspring.

- The Offense Principle involves regulating an actor in order to keep that person from giving serious offense to others. ${ }^{93}$ This could, for example, encompass regulations that prevent people from editing their own genomes in ways that others might find scary or revolting, even if the editing poses no health risks to themselves or others.

- Legal Paternalism involves applying governmental coercion to people to prevent the actors from harming themselves. ${ }^{94}$ This would encompass regulations aimed at stopping people from editing their genomes in ways that might be medically risky or harmful to their own health.

- Legal Moralism approves the use of coercion to stop activities that do not necessarily harm or offend the actor or other people, but which seem inherently immoral or might cause broad harms to society or undermine morality in general. ${ }^{95}$ This is reminiscent of "the wisdom of repugnance" or "yuk factor," that Leon Kass advanced as a reason to reject human cloning. ${ }^{96}$ It also encompasses a view that I refer to as "wildism," the conviction that human gene editing should be avoided because people with pure, natural, wild-type human genomes are physically or morally superior to those who tamper with their native genetic purity. ${ }^{97}$

Feinberg regards the Harm Principle and the Offense Principle as the only justifications for governmental coercion that are consistent with liberal principles. ${ }^{98}$ He notes that John Stuart Mill rejected Legal Paternalism as grounds for state coercion, viewing the goal of preventing self-harm

\footnotetext{
${ }^{89}$ JOEl FeINBERG, MORAl Limits of THE CRIMINAL LAW Volume 3: HARM to SELF, at xvi-xvii (Oxford Univ. Press 1989).

${ }^{90} \mathrm{Id}$.

${ }^{91} \mathrm{Id}$. at xvi.

${ }^{92} \mathrm{Id}$.

${ }^{93} I d$. at xvii.

${ }^{94} I d$.

${ }^{95} \mathrm{Id}$.

${ }^{96}$ Leon R. Kass, The Wisdom of Repugnance, NEW REPUBLIC, June 2, 1997, at 17.

${ }^{97}$ Evans, supra note 46.

${ }^{98}$ FEINBERG, supra note 89, at 3.
} 
as appropriate grounds to reason with people and attempt to persuade them to stop what they are doing, but not as grounds for compelling them to stop or punishing them if they persist. ${ }^{99}$

Feinberg spills considerable ink reconciling the fact that many laws do seem paternalistic, even if the Harm and Offense Principles may, in theory, be the only legitimate grounds for governmental coercion. "[T] he view that the state has a right to protect people from their own folly seems to provide the rationale for many [laws] that nobody would wish to repeal." ${ }^{00} \mathrm{He}$ distinguishes "presumptively non-blameable" paternalism (exemplified by laws protecting genuinely vulnerable populations such as the elderly, the decisionally impaired, and children) from paternalism that is "presumptively blameable". ${ }^{101}$ Under this latter category, he includes two concepts. The first is paternalism that is "benevolent" and well-intentioned in the sense of trying to protect people, but which overrides the autonomy of informed, competent adults who are neither vulnerable nor wish to be protected. ${ }^{102}$ The second is "non-benevolent" paternalism that dresses itself up as laws to protect people but, in reality, promotes unrelated goals such as industrial efficiency or liability risk management.

Another important point is that some regulations are grounded in more than one principle, and the legislative intent is sometimes unclear or unstated. Some laws that seem paternalistic are, in fact, "mixed paternalistic laws" serving multiple objectives. ${ }^{103}$ A regulation might be motivated by "the need to protect the directly restricted party himself; but also to protect third parties from indirect harm, and even the general public from a kind of diffuse harm." ${ }^{104}$ This soup of benevolent and non-benevolent paternalism is common in modern bioethical analysis. An example is policies that seek to limit individuals' access to their own genetic and other health information. There is a benevolent concern that people may misunderstand their data, worry, or make bad medical decisions after they receive it.. ${ }^{105}$ Simultaneously, there are non-benevolent concerns that sharing such data may be burdensome for researchers and waste scarce research and healthcare resources. ${ }^{106}$

Feinberg recognizes that law has a useful role to play in ensuring that people's choices reflect their true will. He describes "soft paternalism," in which laws seek to ensure that people's decisions are competent, voluntary, and well-informed, but respect their choices once these conditions are met. ${ }^{107}$ This approach is common in research regulations such as the Common Rule $^{108}$ and the FDA research regulations, ${ }^{109}$ which allow people to expose themselves to research risks subject to protections to promote well-informed, autonomous decisions. Once those protections are in place, however, Feinberg's anti-paternalistic view respects people's right to make their own decisions. ${ }^{110}$

\footnotetext{
${ }^{99} \mathrm{Id}$.

${ }^{100} \mathrm{Id}$. at 4.

${ }^{101} I d$. at 5.

${ }^{102} \mathrm{Id}$.

${ }^{103}$ Id. at 16.

${ }^{104} \mathrm{Id}$.

105 See NAT'L ACADEMIES SCI., RETURNING INDIVIDUAL RESEARCH RESULTS TO PARTICIPANTS: GUIDANCE FOR A NEW RESEARCH PARADIGM 61 (Jeffrey R. Botkin et al. eds., Nat'l Academies Sci. 2018) (discussing harms people may suffer if granted access to test results generated during genomic and other types of research).

${ }^{106} \mathrm{Id}$.

${ }^{107}$ Id. at $13-14$.

10845 C.F.R. pt. 46, subpt. A (2018).

10921 C.F.R. pt. 50, 54, 56 (2019).

${ }^{110}$ FEINBERG, supra note 89, at 2 .
} 
In reality, law frequently rejects this advice. An early example, dating back to the 1600's, is Wright's case, which is the English case in which an adult man consented to have another person cut off his hand with the aim of enhancing the man's earnings as a beggar. ${ }^{111}$ The accomplice was later charged with mayhem and cited the man's consent as a defense, but without success. Such a consent was invalid, the court reasoned, because it sought to deprive the King of the able-bodied work capacity of one of his subjects. ${ }^{112}$ In other words, the court resolved the case under the Harm Principle (the man had no right to harm the King), instead of on anti-paternalistic grounds.

Wright's case presents other nuances that are pertinent to regulation of DIYbio. There is a difference between "single-party" self-harm (doing harm to oneself) and "two-party" cases in which a person enlists the aid of others. ${ }^{113}$ A person's consent to self-harm often exculpates accomplices to the self-harming scheme, but law treats certain consents, particularly when the consent is to an outrageous act, as void for public policy reasons. In coming years, courts may have to set boundaries on which types of gene editing are within the limits of individual consent. A related question is whether the ostensible right to harm oneself encompasses a right to risk harming others by involving them in one's scheme. Those harms to others could include psychological harms such as feeling guilty or various legal risks if the scheme goes awry and has unintended consequences. The reason to restrict DIY genomics may not be Legal Paternalism (preventing harm to the individual) but rather the Harm Principle (keeping the individual from harming others).

With that background, let us turn back to the question of how FDA should regulate DIYbio in which the person who produces a medical product will be its only consumer. This would exclude intra-family consumption, for example, if a parent performs at-home gene editing on a child with a rare genetic disorder. That latter situation clearly falls under the Harm Principle, and FDA potentially could require the parent to obtain an investigational new drug (IND) application before administering the unapproved therapy to the child. While there is some room for debate, FDA officials have suggested in the past that the agency can require an IND in sponsor-investigator studies (where the research sponsor is the same as the investigator, in this example, the parent) even if the study has no commercial motive and there are no plans to submit study results to the FDA. ${ }^{114}$ If true, the agency has legal authority to oversee the parent's experiment, but would face all the practical barriers the previous section described. In particular, how would the FDA know the research is happening? This seemingly is a matter for state children's protective services agencies. State legislatures may soon need to update mandatory reporting statutes to require physicians, teachers, and daycare providers to report suspicions about inappropriate DIYbio research involving minors.

When an adult of sound mind is both the producer and the only consumer of a DIYbio product, FDA involvement seems legally inappropriate. Feinberg is technically correct that the FDA's medical product regulations implement the Harm Principle and are not grounded in Legal Paternalism. ${ }^{115}$ Placing the FDA into a new role of protecting people from themselves would mark a fundamental departure from Congress's scheme of medical product regulation. This is not to deny, however, that FDA's policies can seem paternalistic in fact, even when those policies are

\footnotetext{
111 See ARTHUR RIPSTEIN, ForCE AND FrEEDOM: KANT's LEGAL AND POLITICAL PHILOSOPHY 133 (2010); Vera

Bergelson, The Right to be Hurt: Testing the Limits of Consent, 75 GEO. WASH. L. REV. 165, 173 (2007).

112 Bergelson, supra note 111.

${ }^{113}$ FEINBERG, supra note 89 , at 9.

${ }^{114}$ Lynn Henley, Clinical Investigator Training Course: How to Put Together an IDE Application, U.S. FoOD \& DRUG ADMIN. (Nov. 14, 2013), https://www.fda.gov/media/87607/download.

115 FEINBERG, supra note 89, at 21.
} 
nominally grounded in other principles. This is the agency that fought long court battles to prevent dying cancer patients from risking their health by taking Laetrile ${ }^{116}$ or by trying experimental therapies that had not yet completed all three phases of clinical trials. ${ }^{117}$ Moreover, the notion that the FDA regulates producers, not consumers, runs up against cases like Kessler v. Benten, in which a woman purchased mifepristone (a drug that blocks the female hormone progestin) overseas for her own personal use, only to have it confiscated when she returned to the United States. ${ }^{118}$ Despite that case, however, the agency often takes a non-paternalistic stance on imports for personal use, allowing consumers to import unapproved pork and beef insulin for their own consumption even though these products carry potentially serious risks, including the risk of transmitting mad-cow disease. ${ }^{119}$ Perhaps the Benten case is an outlier that rests on the Harm Principle rather than Legal Paternalism: the consumer stated she intended to use the mifepristone to induce an abortion, raising concerns about harm to the fetus. The drug has various other medical uses and perhaps could have been imported had she cited one of those.

There is probably only a small number of DIYbio producer/consumers who desire to edit their own genomes and have the skills and determination to do it. It is inappropriate for the FDA to interfere with their activities. Regulation is, however, appropriate if such people offer their products to other consumers. This leaves the agency ample room to regulate individuals who manufacture biotechnology products for use by other people, while preserving a crucial space for citizen science and innovation within the narrow producer-as-consumer business model. DIYbio practitioners who publish their gene-editing instructions seemingly enjoy First Amendment protection unless this literature is prepared and/or distributed in a manner that causes it to become part of labeling for a gene-editing product that they or someone else is marketing. ${ }^{120}$ For reasons discussed earlier, software service providers and contract laboratories with which DIYbio practitioners do business may, in many instances, fall outside FDA jurisdiction. Some may regard these limits on the agency's jurisdiction as a matter of deep concern; others may view them as providing an important frontier for scientific and business-model innovation.

\section{Conclusion}

Viewed through the lens of Professor Ikemoto's "frontier" narrative, DIYbio offers a space of hope for rare-disease sufferers whose maladies affect too small a population to induce public funders and commercial biotechnology companies to invest in developing effective treatments. It is a space for pursuing enhancement, in a research ethical and funding environment that necessarily, but drearily, prioritizes the treatment of serious diseases over finding ways to make healthy people happier. DIYbio offers a frontier of science in service of what people actually want, instead of what ethicists, funding agencies, and commercial product developers think they ought

\footnotetext{
116 U.S. v. Rutherford, 442 U.S. 544, 546 (1979).

117 Abigail Alliance v. Von Eschenbach, 495 F.3d 695, 697 (D.C. Cir. 2007), cert. denied 128 S. Ct. 1069 (2008).

118 Benton v. Kessler, 799 F. Supp. 281, 284 (E.D.N.Y. 1992) cert. denied 515 U.S. 1084 (1992).

${ }^{119}$ See, e.g., Questions and Answers on Importing Beef or Pork Insulin for Personal Use, U.S. FOOD \& DRUG ADMIN. (Oct. 28, 2015), https://www.fda.gov/Drugs/ResourcesForYou/Consumers/QuestionsAnswers/ucm173909.html; see also Is it Legal for Me to Personally Import Drugs?, U.S. FOOD \& DRUG ADMIN. (Mar. 28, 2018) https://www.fda.gov/AboutFDA/Transparency/Basics/ucm194904.html.

${ }^{120}$ See, e.g., Kordel v. United States, 335 U.S. 345, 346 (1948); see also United States v. 24 Bottles "Sterling Vinegar \& Honey," etc., 338 F.2d 157, 158 (2d Cir. 1964) (delineating circumstances in which FDA can regulate published literature as part of product labeling).
} 
to have; supplied at prices they frequently cannot afford. Above all, it is a space for pursuing science as an expressive activity and provides an important space for business model innovation. There are regulatory gaps in the current Coordinated Framework, leaving aspects of DIYbio unregulated or ineffectively regulated. Before crafting governmental or non-governmental mechanisms to fill those gaps, there first needs to be a careful dialogue about the goals of regulation and appropriate principles to guide future regulatory efforts. 